86. 2,3 の疾患時の尿中ビタミン排 泄について

$$
\begin{array}{r}
\text { 吉利 和, 柴田 長夫, 前田 貞亮 } \\
\text { 山下 政三, 安田 和人, 山本 学 } \\
\text { (東京大 } \cdot \text { 医・吉利内科) }
\end{array}
$$

一般に健康人の尿中ビタミン $\mathrm{B}_{1}$ 排泄量は, その時そ の時の食物からの $\mathrm{B}_{1}$ 摂取量によって影響を受け, 毎日の 摂取量が多ければ多く，少なくなれば速かに減少する。

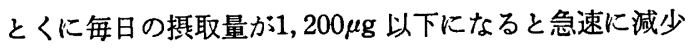
する。したがって尿中 $\mathrm{B}_{1}$ 排泄量を測定すると生体のビ タミン $\mathrm{B}_{1}$ 栄養状態はお扰よそ推定することができる。 これは健康人だけでなく多くの疾患の場合にも見られる 現象であるが, 肝疾患や Basedow 病のような場合には容 易に排泄されてしまう。今回は $\mathrm{B}_{1}$ 摂取量が異常に高い にもかかわらず，尿中排泄量は対照に比べて非常に少な い疾患について記す。(1)腎疾患：軽症の場合には対照と ほとんど差がないか，腎障害の高度な場合には $\mathrm{B}_{1}$ が経 口または注射で投与されても尿中 $\mathrm{B}_{1}$ 量は極めて少な く，ときには全く排泄されない。これは尿の色調, 比重, 血中尿素量, GFR, RPF などの変動とよく平衡して動 く。この場合には $\mathrm{B}_{1}$ を大量に注射しても尿中への排泄 量は少ない。したがって堅機能障害時には 1 日尿中 $\mathrm{B}_{1}$ 量から生体の栄養状態を推定することは困難である。(2) 吸収不良性症候群： $\mathrm{B}_{1}$ を経口投与で与えると少量の場 合は割合に上く吸収されるが，大量の $\mathrm{B}_{1}$ 誘導体の経口 投与時の吸収量は少ない。たたし，非経口投与で与兄ら れた場合の尿中 $\mathrm{B}_{1}$ 排泄量は著しく增加する。本症候群 では経口と非経口投与による尿中排泄量が高度なので, 生体の $\mathrm{B}_{1}$ 栄養状熊の改善には注射を必要とする。

87. 1 日食慨中の V. $B_{1}$ の配分と栄 養効率の関係について（第 2 報）

$$
\begin{aligned}
& \text { 佐伯 芳子, 佐伯 篤, 鈴木 義昭 } \\
& \text { 萩野 寿子, 竹中 幸子, 藤原策太郎 }
\end{aligned}
$$

(佐伯栄養学校)

著者らはさきに，計算値上では同一の栄養価を示す完 全食餌中の V. $B_{1}$ について，その総提取量は等しい場合 においても，これを毎回の食慨と共に分割摂取する場合 と，1日 1 回総量を撕取する場合とではその尿中排泄総 量に大羑の生ずることを認め, さらにその 24 時間内にお ける排泄量について, 1 日投与総量が成人の要求量 1,300 rである場合においてい, 時間的の差異が認められるこ とおよびこの 2 者の排泄量の時間的変化のカーブにはそ れぞれ異なった型がみとめられることを報告した。
今回は，V. $B_{1}$ 投与量が通常の要求量を上回わる 1 日 総量 3,000 r の場合においても前回の試験と同様の結果 が得られるか否かを検し，またいずれる標準食の範囲内 であるが，前回のような普通の成分構成をるつ食餌の場 合と比べて高脂肪食といえる食慨についても同様の試験 を行なった。

また, 同時に血中 Cholesterol 值㧍よび Glucocorticoid の尿中排泄量などを測定した。

実験方法としては, 諸条件の合致する成年男子学生 6 名を被検者とし， 1 週間の標準食投与期の後これを 2 群 に分ち，V. $B_{1}$ のみ久乏する同一の完全食を与充，さら にそれにB群には V. $B_{1} 3,000 \gamma$ を早朝すべての食飭と 隔絶して投与し, A群には毎回の食慨と共に V. B 11,000 rずつを分割投与した。

各湘定は24時間を（1)早朝摂取時より朝食まで，(2)昼 食後まで，(3)夕食後まで，(4)翌早朝までの 4 期に分ち各 々の比較を行なった。

食慨は普通食としては 1 日量糖質 $500 \mathrm{~g}$, 脂肪 $27 \mathrm{~g}$ とし, 高脂肪食としては 1 日量糖質 $290 \mathrm{~g}$, 脂肪 $132 \mathrm{~g}$ を与えた。

結果は血中 Cholesterol 值はいずれの場合にも正常値 の範囲内にありその他身体一般条件もまた同じであっ た。

V. $\mathrm{B}_{1}$ 尿中排泄量の時間的変化の関係は普通食餌およ び高脂肪食餌の場合のいずれにおいても前回と同様の型 を示す。

88. ビタミン $\mathrm{B}_{1}$ 久乏時におけるラ ット肝細胞のタンパク質合成に つ৬て

$$
\begin{aligned}
& \text { 中川 眸（富山大·教） } \\
& \text { 大浦颜吉（富山大·蒋） }
\end{aligned}
$$

Wettstein ら (Nature., 197, 430, 1963) によって, ラット肝細胞質からリボジーム集合体すなわち，ポリヅ 一ムが分離されこのものがタンパク質合成の活性体であ ることが明らかとなり，その後多くの報告がある。

Sidransky ら (Science, 146, 766, 1964) は, スレオ ニン欠乏食慨を短期間 ( 3 日間) 投与したラット肝細胞 において, タンパク質合成の活性はむしろ增大し，庶糖 密度勾配遠心パターンは会合度の大きい重いリボゾーム の增加を報告している。

脱炭酸酵素の補醉索であるビタミン $\mathrm{B}_{1}$ の欠乏食飭を 投与した場合，約 2 週間後にラットの体重は減少しはじ め, 約40日後に極度に減少するが，この時期にビタミン $\mathrm{B}_{1}$ を投与すれば，体重は急激に回復する。 
今回この過程を(A)体重の增加期, (B)減少期, (C)回復期 に区分して, 各期の畈ポリジームをミトコンドリア沈降 上清および精媻ポリゾームについて，庶糖密度勾配遠心 パターン ( $1 \mathrm{M}-0.3 \mathrm{M}$ 庶糖濃度)で解析した。

精製ポリゾームおよび上清ポリゾームでは体重の減少 に平行して，会合度の大きい大部分のポリゾームが崩壊 し, monomer, dimer, trimer の增大が認められ, ま た，肝の重量および肝リボゾームの収量も同様に減少す る。

さらに ${ }^{14} \mathrm{C}$-ロイシンを用いて in vivo, in vitro での タンパク質合成の活性を検討中である。

このことから，ビタミン $\mathrm{B}_{1}$ 欠そによって，ATP の 生成系が阻害され，これによって，RNA，タンパク質の 合成が重大な影響をうけることが考えられるので，今後 さらに，各種の RNA 合成についても検討を進めたい。

89. 飢餓による白臼蔵器 NAD 量と NAD 分解酵素並びにその他 2 ,

3 の酵素活性の変化について

下山 誠, 大田 元治, 山口 賢次 上田 票夫 (大阪医大・医化学)

動物体内に扰けるNicotinamide adenine dinucleotide (NAD) の生成は Nicotinic acid, Nicotinamide を素 材として行なわれる外, Tryptophan から Quinolinic acid を経て行なわれることが明らかにされている。動物 を飢餓状態に扣いたときは NAD 合成素材の外部からの 供給が絶たれることになり，NAD 量は当然低下するこ とが推測され，他方飢餓時においてもエネルギーの産生 その他の生活現象を営むための多くの反応で NAD は重 要な助酵素として必要である。演者らは絶食状態に拉け る動物䁍器 NAD 量と NAD 分解活性の変化を明らかに する目的で, 白鼠を絶食状態に扣き 120 時間までの肝, 腎および脾の $\mathrm{NAD}$ 量を $\mathrm{ADH}$ 法扰よび $\mathrm{KCN}$ 法を用 いて測定した結果いずれの藏器においても ADH 法では 絶食持続時間の経過に伴い,僅かな減少を認めたが $\mathrm{KCN}$ 法では腎および脾は絶食状態が長くなるに従って增加の 傾向を示し, 絶食 144 時間では絶食前に比較し著明な上 年を示した この 1 部は昨年の日本栄養・食糧学会近畿 支部大会で報告した)。また正常および飢餓白鼠腹腔内 に Nicotinamide $(500 \mathrm{mg} / \mathrm{kg})$ を注射して 5 時間後の各 臟器に含有される pyridine-nucleotide 量を KCN 法に より測定したところ, 絶食 144 時間では正常に比し肝に おける含量はやや減少するが，腎および脾では增加し， Amide を注加しない場合とほは同じ傾向を示した。ま たこの場合, ADH 法により NAD 量を測定した結果,
飢餓 144 時間に扰いては絶食前に比較して肝では減少し たが腎および脾ではかえって增加した。以上の結果と正 常および飢餓時の白鼠に Nicotinamide を注加した場合 の各臓器の NAD 分解醅素活性の変化とを考方併せて飢 餓時に㧊ける NAD level の変動について検討した。ま た飢䄉時の他の 2,3 の酵素活性の变化についても報告 ・する。

90. 微結晶セルロース添加による低 カロリ一食品の利用とビタミン $\mathrm{B}_{1}$ 吸収

$$
\begin{aligned}
& \text { 吉利 和, 柴田 長夫, 赤沢 北生 } \\
& \text { 安田 和人, 山本 学 }
\end{aligned}
$$

（東京大・医・吉利内科）

加水分解して分子の重合度を一定化した微結晶セルロ 一スを混入して低カロリ一食品をつくり，食慨の熱量を 減らす必要のある患者に与えることは, 一応の満足感を 得させ減食の指示を守らせるのに好都合な場合がある。 しかし主食としてるちいる時は, 菓子など従来のセルロ 一ス添加食品にくらべてかなり大量を長期にわたり摂取 することになるので腸内菌叢の荾化, 吸着性などにより ビタミンの吸収に影響を与えてはならぬと考え，まず $\mathrm{B}_{1}$ について検討した。体重約 $60 \mathrm{~g}$ の雄シロネズミを $\mathrm{A}$ 一対 照飼料(カゼイン 20 , 澱粉 68 , 大豆油・肝油 8 , 塩類混合 4 \%), B-5\%七ルロース加飼料, C-10\%七ルロース加飼 料を自由に与え $\mathrm{B}_{1} 40 \gamma$, 他の B 群ビタミン十分量を毎 日経口摄取して 4 週間飼育し, 体重, 搨飼量, 粪量, 尿· 䔬中 $B_{1}$ 排泄量の経過を観察し, 飼育期終了後直ちに血 液・主要藏器 $\mathrm{B}_{1}$ 濃度, 末梢血液像, 血清総蛋白, 総二 レステロールなどを測定した。

尿中 $\mathrm{B}_{1}$ 排泄量, 血液・主要臓器 $\mathrm{B}_{1}$ 濃度には 3 群の 間に有意の差をみとめず,末梢血液像, 血清蛋白, 総コレ ステロールなどにも各群ともとくに変動をみとめなかっ た。供量は $\mathrm{B}, \mathrm{C}$ 群では $\mathrm{A}$ 群にくらべて增加し, 䔬中 $\mathrm{B}_{1}$ 排泄量は $\mathrm{B} ， \mathrm{C}$ 群とも增加したが結合型 $\mathrm{B}_{1}$ の增加が著 明であって, 遊離型 $\mathrm{B}_{1}$ はほとんど変動をしめさなかっ た。また $\mathrm{A}, \mathrm{C}$ 群の一部は $\mathrm{B}_{1}$ を投与せずに飼育し $\mathrm{B}_{1}$ 欠乏症状の発現, 経過を比較したが両群の間にほとんど 差をみとめなかった。

また健康成人男子 7 名に同セルロース添加食品を 10 日 間摂取させ, その前後の血液 $\mathrm{B}_{1}$ 濃度, 尿 ・顀中 $\mathrm{B}_{1}$ 排泄 量を測定したが, いずれす有意の変動をしめさなかっ た。

（結論）糞中 $\mathrm{B}_{1}$ 排泄量の增加は主として腸内細菌に由 来するすのと考えられ, 翼中の遊離 $\mathrm{B}_{1}$ は增加せず血液・ 


\section{栄 養}

㬴器・尿中 $\mathrm{B}_{1}$ に有意の变動をみとめぬところから微結 晶セルロース添加食品の利用にあたり通常の条件のもと では $\mathrm{B}_{1}$ の吸収に障害を来たすことはないるのと思われ る。

\section{1. スグキ漬に関する研究（第 5 報）} ビオチンおよびその他のB群ビ タミンの分布と分離乳酸菌の栄 美要求について

福原 貞介, 栃倉辰六郎, 緒方 浩一 （京都大・農・発酵生理）

演者はすでに上加茂のスグキ漬につき，その熟成工程 中における微生物相の变遷, 主要成分の消長を究明する 一方, 熟成に関与する多数の乳酸菌を分離した。また幋 造工程の科学化を目標に分離菌添加の応用実験を行な いお拈むねその目的を果した。スグキ熟成の際雑菌の 䇣殖を扣さえ乳酸菌の選択的增殖を可能とするには樽内 の環境的諸条件の適正化をはかると同時に必須栄養成分 の補給が大切である。これは栄養要求が複雑な乳酸菌の 場合特に重視すべき条件といえよう。そこで今回はスグ キ漬の乳酸菌による熟成機構を解明する基碟研究の一環 として，スグキエキス単独あるいはこれにカサミノ酸, シスチン,トリプトファン, 核酸塩基などの成分を追加 した培地について乳酸菌の生育を比較し，エキス中の栄 養成分を予測する一方スグキより分離した乳酸菌代表株 につき $\mathrm{B}$ 群ビタミン, フミノ酸, 核酸塩基などの基本的 栄盖要求の予測を行なった。つぎにスグキの原料扣よび 慗品のビオチンその他のB群ビタミン,グルタミン酸, グ ルタミンの分布を比較測定した。測定はいずれもハイイオ アッセイ法によった。その結果スグキ根のエキス中には アミノ酸，核酸塩基などの必須養分の欠乏していること が明らかになった。また分離株(AT. 14)の生育にはB B群 ビタミンとしてビオチン, ニュチン酸, パントテン酸, $\mathrm{B}_{2}$ の 4 種, アミノ酸としてグルタミン酸, シスチン, ト リプトファン（外に数種のアミノ酸が必須と推定される が未決定), 核酸塩基としてグアニン，アデニン， ウラ シルを必須成分として要求することを認めた。そこでこ れら必須成分のうちビタミン,グルタミン酸の最大要求 量を分離菌の maximum growth から求めたところ 4 $\mathrm{ml}$ (tube) 当たり $\mathrm{B}_{2} 0.5 \mu \mathrm{g}$, ビオチン $1 \sim 1.5 \mathrm{~m} \mu \mathrm{g}$, = コチン酸, パントテン酸 $0.2 \sim 0.3 \mu \mathrm{g}, \quad l$ グルタミン酸 $200 \mu \mathrm{g}$ であった。この最大要求量の数字は生スグキ中の 分布量にくらべるといずれもはるかに少ない。したがっ てスグキ熟成中に乳酸菌の增殖が促進される理由はここ にも存在することがわかった。

\section{2. 食品のビタミン $\mathrm{E}$ 効果について} 小柳 達男, 和田 せつ (東北大・農)

乳離れ直後のドンリュー系雌白ネズミにビタミン $\mathrm{E} 欠$ そ飼料を与克，50日余飼育した後健康な雄成熟ネズミと 交配した。そしてスメアテストにより受胎を認めたるの に直ちに諸種の食用油または抽出物, あるいは食品を 3 日間食䬺に添加し，これらを与えない無処理群あるいは $\mathrm{E}$ 標準品を 3 日連続投与した対照群と比較した。試験に 供した試料は大豆エーテル抽出またはアルコール抽出 物, 玄米アルコール抽出物, マヨネーズから分離した油, コーンサラダ油, 市販天ぷら油,キャベッ青葉などで, 標 準 $\mathrm{E}$ とては dl- $\alpha$-トコフェロールアセテートを含む動 物用 $\mathrm{E}$ 版を用いた。給与量は油または抽出物は $1 \mathrm{~g} /$ 日/匹

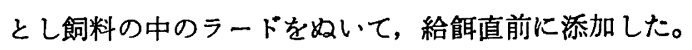
標準群には $\alpha$ ートコフェロールアセテート $3 \mathrm{mg} /$ 日/匹相 当量を与えた。キャベッは青葉のみ $70 \mathrm{~g} /$ 日沉を欠之食 にそえた。妊娠継続19日目に開腹し, 子宮, 卵巣をとり 出して排卵数, 着床数, 生胎児数, 生胎児および胎盤重 量を測定し,また肝臓, 腎蔵, 心蔵, 脾臓, 副腎, 屠体 重なとから栄養状態を比較した。実験は 2 回に分けて行 なった。

これらの試験群はいずれす同様に妊娠したが，妊娠後 も $\mathrm{E}$ 久乏食のみ与えたすのは例外なく流産して生胎児は 全く存在しなかった。排卯数, 着床数は各試鈳群間に差 異は殆んど認められないが, 生胎児数は添加試料により 異なり, 一腹の平均生胎児数は大豆エーテル抽出物, 市 販フライ油 $(\mathrm{H})$, マヨネーズ分離油( $\mathrm{K})$, 青キャペッ添 加群は何れも0で, 大豆アルコール抽出物, 玄米アルコ 一ル抽出物, コーンサラダ油, 市販天ぷら油 (A) はそ れぞれ平均 $2.0 ０ .9 ， 1.5 ， 2.3$ であった。標準群はは じめからEを添加飼育した正常群とかわらず, 平均生胎 児数は 9.8 あるいは 10.8/腹であった。大豆や玄米のア ルコール抽出物の添加量をふらすを完全に妊娠し, 生胎 児も大きくなることが推定された。

\section{3. $\alpha$ ートコフェロール欠乏時におけ

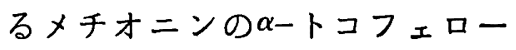 ル代替効果について}

稲垣 長典, 福場 博保, 刑部 晶子 金光千恵子（打茶の水女子大）

Schwarz らは含硫フミノ酸に $\mathrm{E}$ 節約作用があること を認めている。本研究は $\mathrm{E}$ 欠乏時のメチオニンの効果に ついて，白ねずみを用い次の 6 群に分けて実験した（3 週間)。すなわち，A群：蛋白レベル $5 \% \mathrm{E}$ 久飼料，B群 
: A 群十メチオニン (50 mg/day, rat), C 群 : $\mathrm{A}$ 群十 $\mathrm{E}(0.5 \mathrm{mg} / \mathrm{day}, \mathrm{rat}), \mathrm{D}$ 群：蛋白レベル15\% $\mathrm{E}$ 久飼料, $\mathrm{E}$ 群 : $\mathrm{D}$ 群十メチオニン $(50 \mathrm{mg} / \mathrm{day}, \mathrm{rat}), \mathrm{F}$ 群 : D 群 +E (0.5mg/day, rat) とした。判定方法としては溶血 反応, 肝ミトコンドリアのコハク酸脱水素酵素, シンゴ酸 酸化䤃素活性, および生長状熊, 肝重量, 肝脂肪, 肝脂 肪組成を測定することによって行なった。以上の結果よ り，体重增加にてはメチオニン添加群は優れていたが, 溶血反応においてはメチオニンの勃果を認めることがで きなかった。また各䣼素活性実験です各群に有意差を認 めることができなかった。

94. 食品中のコレステロール量につ いて（日本食の研究・第40報）

古賀 菱子, 加藤 祥子 (中村学園大) 木村 峯子(第一薬大・生化)

老人食研究の一部として, 動物性食品 145 品について その抽出脂肪中のコレステロールを定量した（脂肪战化 後, エーテル抽出, Liebermann-Burchard 法)。魚類に ついては出回り期を中心に他の時期のものも加えた。ま た肉部のほか皮部, 内荿部や卵も検査した。酪農品とし ては内外諸社慗のチーズと国産のバター、マーガリンを 材料とした。ニレステロール量は食品中と脂肪中の $\mathrm{mg}$ \%を計算すると同時に蛋白質 $100 \mathrm{~g}$ と共に存在する $\mathrm{mg}$ 数を計算し（Nと灰分を定量）これをコレステロール蛋 白係数 (以下係数と略称) と仮称する。魚肉38品中係数 のもっとも小さいものはカッオ普通肉 (S. 40.6.8) (以 下（）内には入手年月日を示す） 27 , 同上 (S. 40.4.22) 49, サバ普通肉 (S. 39.11.26) 74，マグロ (S. 39.12.15) 135, 冷凍ダイ (S. 40.6.8) 146 などでホウボウ, マアジ 普通肉, カッオ血合, 冷凍ホウボウ, 小ダイ, アカマダ イ，サパ，マアジ (血合) などがこれに次ぎ最も大きい のはウナギ (S. 40.7.28) 1, 435， マフナゴ (S. 40.8.27) 2,893 であった。一般に肉部, 皮部 (19品)，内藏 (14 品) の順に大で, 卵, 白子類(11品)も肉部より大であっ た。血合肉は白味肉より概して大である。

甲殼類, 頭足類15品中シバェビ (S. 39.11.19) 107 で 比較的小, カ二(S. 40.2.28) 409, タコ,イイダコこれに 次ぎ甲イカ（S. 40.5.8）1,440, ヤリイカ（S. 40.4.8） 1,937 の順に大で, カ二の卵, 甲イカの内臓はさらに大 であった。貝類14品間には大差なく比較的大である(483 $\sim 2,286$ )。

鳥獣肉扣よびその加工品24品中少ないのは鯨赤身109, 鵎ささ身 185 , 牛フィレ肉, 牛シチュウ肉, 眽腿肉これ につぎ熎肝は 400 ，豚肝 $1,576 ，$ 牛肝 2,007 であった。
酪晨品中バター 9 種を測定した。脂肪中のコレステロ ールの $\mathrm{mg} \%$ は天然バター295〜335，マーガリン 154, 156，192，281を示したが純植物性と表記しながら1, 298 $\mathrm{mg} \%$ を示すものもあった。内外のチーズ 10 種の係数 は245〜430を示し概してコレステロールの少ない食品と みなし得る。

95. 食用キノコ類のシロネズミ血漿 コレステリン代謝におよぼす影 響（III）

德田 節子, 金田 尚志（東北大・農）

演者らはすでにシイタケが著しくシロネズミの血漿コ レステリンを低下させる作用のあることを見出している が，今回は形態の異なるシイタケの効果の程度およびシ イタケ菌柄, シイタケ以外の食用キノコの効果の有無な どについて検討した。すなわちシイタケ香信，ドンュ， エノキダケ，マッシュルーム，キクラゲおよび香信の菌 柄を試料とし動物試験を行なった。その結果, ドンコと よばれる肉厚のシイタケはその作用もっとも強く，香信 はドンュよりいくぶん劣った。またマッシュルームはド ンコと香信の中間に位した。シイタケ菌柄は子実体より 劣るが効力を有していた。またエノキダケ、キクラゲは 有効だがシイタケに劣った。

既報のようにシイタケの有効成分は水溶性だが $80 \%$ 工 タノールに可溶, 無水エタノールに不溶なことも見出し た。

96. 大豆ステロールおよびューンス テロールの血漿および肝臓コレ ステロールレベルに及ぼす効果

道 喜美代, 中山 德子, 江沢 郁子 （日本女子大）

前報において大豆油およびューンオイルの分子蒸留初 留区分に血漿, 肝臟コレステロールを低下させる效果を 認め, この区分に含まれる不畧化物の効果と考えられる 結果を得たので，今回は不跧化物区分に含まれる結晶性 大豆ステロールおよび，コーンステロールにつき，高コ レステロール血症に対する効果を試験したので報告す る。成熟雄白ネズミを用い高コレステロール血症を起こ す飼料にリノール酸グリセライド区分添加（I）を対照 とし，これに $0.2 \%$ 大豆ステロール添加(II)，コーンス テロール添加（III）につき試験し，I扰よび皿はIに比 し, それぞれ血漿, 肝および副堅コレステロールの低下 が認められた。なお使用した結晶性ステロールは何れ 
๖,ガスクロマトグラフィーの結果, Campesterol, Stigmasterol および $\beta$-Sitosterol の混合物であること が判明した。

97. 泌乳期別の母乳および母乳のプ ロテオーズペプトン, 非蛋白態 窒素区分のアミノ酸組成

宮沢 久七, 小林鐙一郎, 中平 珠江 （明治乳業研）

泌乳期を 0 〜 カ月(初乳を除く)，2〜 4 カ月， 4 〜 6 カ月, 6 力月以上の 4 区分にわけ各泌乳期の混合母乳 およびそのプロテオーズペプトン, 非蛋白態窒素区分

(PN 区分) のアミノ酸をアミノ酸自動分析機で測定し た。各泌乳期の母親数は $5 \sim 8$ 人で各母親から数回母乳 を採取し混合後測定に供した。

加水分解は蛋白質の約 1,000 倍量の $6 \mathrm{~N}$ 塩酸中で $80 \mu$ $\mathrm{Hg}$ 以下に脱気後 $110^{\circ} \mathrm{C}, 22$ 時間行なった。シスチン, メチオニンは過義酸酸化法 (Moore 1963) でトリプトフ アンはパラジメチールアミノベンッフルデヒド法で測定 した。

母乳拉よびPN 区分の窒素16当たりのアミノ酸の総平 均値は Lys. 7.51 (2.62), His. 2.64 (1.23), Arg. 4.07 (2.11), Asp. 8.82 (4.42), Thr. 4.30 (2.53), Ser. 4. 20 (2.35), Glu. 16.71 (13.62), Pro. 7.57 (3.22), Gly. 2. 36 (1.35), Ala. 3. 65 (2.42), Cys. 1.85 (1.81), Val. 5.63 (2.58), Met. 1.61 (0.57), Iso. 4.75 (1.74), Leu. 9.22 (3.45), Tyr. 3.65 (1. 37), Phe. 3.54 (1.38), Try. 1.63 (0.54) であった。（）はPN 区分のアミ， 酸組成を示す。

泌乳期別の母乳のアミノ酸含量で危険率 $5 \%$ で有意差 が認められたのはグルタミン酸のみで他のアミノ酸は有 意差がなかった。この有意差は PN 区分のグルタミン酸 含量から説明された。PN 区分のアミノ酸含量は低くフ ミノ酸分析で回収されたアミノ態窒素証窒素中の50\%で あった。PN 区分には多量のアミノ糖の他未同定のニン ヒドリン陽性の塩基性物質が多量に含まれこの物質は特 に0〜2 カ月の区分に多かった。

98. 蛋白分解酵素による牛乳蛋白質 の抗原性の減少

丸山 哲彦, 松崎 征子, 宮沢 久七 （明治乳業研）

牛乳蛋白質の抗原性は加熱によっても消失しないこと は免疫電気泳動, Schulz-Dale 反応, PCA 反応などで証 明されている。
演者らは脱脂乳，ホエー， $\alpha_{s}$ カカゼイン, $\beta$-カゼイン， ๔ーカゼイン， $\alpha$-ラクトフルブミン， $\beta$-ラクトグロブリ ソ，オイグロブリン,プソイドグロブリンを放線菌蛋白 分解酵素(プロナーゼ, プロチーム), トリプシン, ペプ シン, パンクレアチン, パパイン,ブロメラインなどで 分解し主として兔疫䉓気涾動で抗原性の消失の有無を湌 討した。醅素量は基質の $1 \%, 37^{\circ} \mathrm{C}$, 至適 $\mathrm{pH}$ で18時間 分解後免疫電気涾動を行なった。

酵素についてはプロナーゼ, パンクレアチン，プロチ 一ムなどが有効でトリプシン, ブロメラインでは多くの 牛乳蛋白区分に抗原性の残存が認められた。牛乳蛋白区 分については $\alpha$-ラクトアルブミン, $\beta$-ラクトグロブリン が比較的抗原性が失われ難かった。

免疫電気泳動で抗原性が消失した試料（プロナーゼお よびパンクレアチン分解物）をさらに鋭敏な PCA 反応 で検討した結果， $\alpha$-ラクトフルブミンのみはなお抗原性 の残存か認められた。

99. 乳児における乳汁カゼインの消 化について (1)

乳児における屎便内燐蛋白燐排 泄率

薢島 翌, 北川 照男 （䒺恵医大・小児科）

乳汁蛋白の消化に関する研究はこれまでに多数報告さ れているが，私どすは乳児における乳汁カゼインの消化 に関する知見を得る目的でまず屎便内燐蛋白煒排泄率の 測定方法を検討し, 併わせて発育に伴 5 燐蛋白燐並びに 蛋白窒素排泄率の消長について測定したので，現在まで に得られた知見について報告する。

測定方法に対する検討 : 燐脂質並びに酸溶性燐を除去 した屎便㔻白分画をアルカリで水解し，燐蛋白から遊離 されたオルト燐酸をカルシウムマグネシウム塩として一 且沈澱させ，これを酸で溶解して Fiske-Subbarow 氏法 で測定して屎便内燐蛋白燐量とした。

私どすは, アルカリ水解の条件と, カルシウムマグネ シウム塩として遊離したオルト燐酸を高い収率で回収す るのに必要な条件について検討し，5\%以下の誤差範囲 でこれを測定し得る方法を定めた。しかし屎便には摄取 燐蛋白以外の, 分泌液や細菌鋠に由来すると思われる燐 蛋白が存在するので，あらかじめ 5 例の乳児を蛋白水解 物に糖質と脂質を添加したミルクで栄趇し，摄取燐蛋白 によらない屎便内燐蛋白 1 日排泄量を測定し，この值を 乳汁篓養児に批ける燐蛋白排泄量から差引いて摄取燐蛋 白に由来するるのの排泄率を測定した。 
〔測定結果】i）各月令を通じて乳児に拊ける燐蛋白 燐の排泄率は蛋白空素の排泄率に比較して著しく低かっ た。

ii）燐蛋白燐の排泄率蛋白空素の排泄率新生児期 において特に高かった。

iii）摂取蛋白が $1.0 \sim 5.0 \mathrm{~g} / \mathrm{kg}$ の範用では, 摂取蛋白 量と燐蛋白燐排泄率との間には一定の関係を認めなかっ た。

iv）燐蛋白燐の排泄率は母乳栄養, 混合栄養, 各種の 人工栄養において特に著しい差異を認めなかった。

v）腸内細菌によってもカゼインは分解されるので, 抗生物質を投与した前後で排泄率を測定したが，著しい 変化を認めなかった。

100. 乳児におりる乳汁カゼインの消 化について (2)

乳児における屎便内カゼイン消 化酵素

井岡佐智子，蓜島翠，北川 照男 （愁恵医大・小児科）

乳児の蒋便内燐蛋白燐排泄率は新生児期に特に高かっ たがこれがカゼインを消化する酵素の活性が低いこと によるか否かを検討する目的で，屎便内のカゼイン消化 酵素について一，二の実験を行なった。

1. 屎便内カゼイン消化酵素の証明

腸内細菌によってもカゼインは分解されるので, 屎便 を生食水で抽出し，超遠心して菌体成分を含む不溶性分 画と，含まない可溶性分画とにわけて，それぞれについ てカゼインの分解酵素活性を測定したところ, 菌体を含 まない可溶性分画にる相当高い䤃素活性を認めた。可溶 性のカゼイン消化醭素の大部分は50\%飽和の硫安によっ て沈涮されたが，この分画でカゼインを処理すると酸溶 性窒素が遊離されると共に, 無機燐す遊離され, その爟 と窒素の比はカゼインK含まれる燐と窒素の比よりゃ や低かった。この分画をさらにセルローズカラムによっ て処理したところ, monoposphatase, 蛋白分解䣼素な どに分離することができたのでその結果についても報告 する。

2. 乳児における屎便内カゼイン消化醅索の消長

健康乳児53例の屎便について，カゼイン消化醭素活性 を単位牪便窒素量の値として測定したところ, 新生児期 儿低く発育と共に上界し，離乳の頃から再びやや下降す る傾向を認めた。しかしながら相当の個体差が認められ たので，同一乳児について経過を追って測定したか，新 生児期の初期には明らかに䣼活性の低いことが認めら
れた。

101. 牛乳および乳児人工栄養品の母 乳化とBifidus 菌に関する実験 と考察 (続報) 酸性乳投与とリ ジン添加ビ菌剤投与による人工 栄養児の腸内菌叢の検索

森 雅央, 小泉 典子（相模女子大）

さきに発表したごとく演者らの実験によれば酸性乳と ビ菌剤の併用による人工栄養児の腸内菌叢は明らかにビ

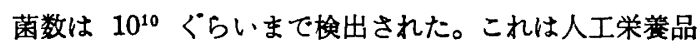
投与期間中，ビ菌剤を連日 $1.5 \mathrm{~g} 3$ 週間投与した結果得 られたものである。そこで今回は酸性乳 Pelargonにり ジンを添加したビ菌剤ラック B-L を1日 $1.5 \mathrm{~g}$ 投与 し, その腸内菌叢と, その乳児の発育状況を観察した。 併わせて Pelargon のみ投与した人工栄盖児の䔬便 $\mathrm{pH}$ 値と，その腸内菌荍を検索し，一般市販調慗粉乳投与乳 児と比較検討した。その結果， $21 \%$ Pelargon の投与児 群は, ビ菌数は $10^{7} \sim 10^{8}$ 位の值を示し, $\mathrm{pH}$ 值は投与前 6.8〜7.0であったすのが，6.2〜6.5の值を示した。対照 の市販調慗粉乳投与児群は, ビ菌数は $10^{7}$ 位にとどまり, 䔬便 $\mathrm{pH}$ 值す 6.8 前後にとどまり，1 例は 7.0 をやや こえる微アルカリ性を示した。翼便 $\mathrm{pH}$ 值の酸性側の值 は,ビ菌の增殖に有効な因子であることが推定された。 なお $21 \%$ Pelargon の投与乳児の発育曲線は標準よりゃ や上まわっていたが，この傾向についてはなお検討の余 地あるを認めた。

次にリジン添加ビ菌剤と Pelargon との併用群のビ菌 数は $10^{9} \sim 10^{10}$ 位を示し, さきの実験と比較しても, ラ ック B-L による侵位は腸内菌数の点では認め難かっ た。

102. 乳汁の複合脂質に関する研究 (2)

りん脂質の分画法および牛乳と 人乳のりん脂質量について

$$
\begin{aligned}
& \text { 土肥 達, 森 茂, 仁木 達 } \\
& \text { 三野 和雄 (雪乳研) }
\end{aligned}
$$

りん脂質を分画する方法には加水分解法, 酸化マグネ シウム吸着法, 硅酸カラムクロマトグラフィーなどある が，どの方法す煩雑であるので，分析方法間の差を検討 しておかなければ実験結果を比較検討することはできな い。本実験では牛乳のりん脂質をそれぞれの方法で 5 回 繰返し実験を行ない, その結果を Tukey の多重検定法 で検討した。つぎに牛乳と人乳のりん脂質量, 各りん脂 
質の割合を測定したのでその結果を報告する。

乳汁のりん脂質量はレーゼゴットリーブ法で定量し た。加水分解法でのコリンはコリン過ヨウ化法により定 量し, 酸化マグネシウム吸着法は常法により, 硅酸カラ ムクロマト法は硅酸: セライト =2: 1を用い,クロロ ホルム:メチルアルコール =98:2, $4: 1,3: 2$, $2: 3,1: 4$ で順次溶出し, 各フラクションのリンを 定量してりん脂質量を求めた。

分析方法間には差があった。牛乳 (20試料) のりん脂 質量は平均 $0.028 \%$, 人乳 (15試料)のそれは平均 0.024 \%と大差ないが, 各りん脂質の割合は表の通りで, 人乳 のスフィンゴミェリンは牛乳の約 2 倍であった。

\begin{tabular}{|c|c|c|c|c|}
\hline & 分 析 法 & $\begin{array}{c}\text { レシチン } \\
(\%)\end{array}$ & $\begin{array}{|rr|}\qquad>7 \\
\qquad(\%)\end{array}$ & 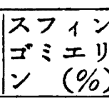 \\
\hline \multirow[t]{2}{*}{4} & 加 水 分 解 法 & 38.6 & 41.1 & 20.3 \\
\hline & 酸化マグネシウム法 & 32.8 & 48.7 & 18.5 \\
\hline 乳 & 硅酸クロマト法 & 36.5 & 42.0 & 21.5 \\
\hline \multirow[t]{2}{*}{ 人 } & 加 水 分 解 法 & 38.5 & 19.4 & 42.1 \\
\hline & 酸化マグネシウム法 & 33.8 & 23.5 & 42.7 \\
\hline 乳 & 硅酸クロマト法 & 30.3 & 30.2 & 39.5 \\
\hline
\end{tabular}

\section{3. クロレラ蛋白質の栄養価 (IV)} 全卵蛋白質，カゼインとの比較

黄 鎬 観, 山口 迪夫, 河口宏太郎 神立 誠（東京大・農・農化）

従来クロレラ蛋白質の栄養価については数多くの試験 が行なわれてきたが, 試料の相違, 随伴物質の影響など により，必ずしも一定の結果が得られていない。本実験

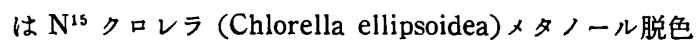
試料を調製し，離乳直後のシロネズミを用い，A）ク口 レラ蛋白質 $20 \%$ ，B）同10\%，C)同10\%+Lーメチオ= 20.37\%，D）全卵蛋白質 $20 \% ， E ）$ 同10\%，F）カゼ イン $10 \%, \mathrm{G}$ ) 無蛋白質， H）無蛋白質飼育 (G) 後ク口 レラ蛋白質 $10 \%$ の各試験区（1区4 頭, 飼育期間 4 日） について, 消化率, 生物価, Net Protein Utilization （NPU）などを測定し，種々の測定法による值を対比 し, 併わせて $\mathrm{N}^{15}$ の主要臓器への取込み, 消化管内にお ける分布などについてる測定し, 蛋白質の栄養価評定法 との関連においても試験を行なった。その結果,

1）体重增加では，メチオニン添加クロレラ蛋白質は およそカゼインに匹敵する値を示した。

2） $\mathrm{N}$ 出納法に上って求めた真の消化率と, $\mathrm{N}^{15} / \mathrm{Cr}_{2}$ $\mathrm{O}_{3}$ に上って求めた消化率では殆んど一致した值が得ら れおよそ80〜85\% のかなり高い值を示した。

3）生物価では約80を示し，メチオニン添加により90
以上となりおよそ全畉蛋白質に匹敵する值を示した。ま た, メチオニン添加における NPU では全卵蛋白質, カ ゼインに比し10\%近く劣る値を示した。

4）クロレラ蛋白質のいずれの区においても， $\mathrm{N}^{16}$ 出 納/摂取 $\mathrm{N}^{15}$ と NPU の值が殆んど一致したことはNPU の評価の上で重要な意味をすつるのと思われる。

5）消化管内に括ける $\mathrm{N}^{15}$ 濃度から, Metabolic $\mathrm{N}$ は 盲腸以下で選択的に再吸収すると思われる。

6) $\mathrm{N}^{15}$ の臓器への取込み量は, 全般的に $20 \%$ 区は10 \%区に比べてほほ等しい割合で高い値を示し，またメチ オニン添加によって脾臓への取込みが增加することが示 された。

\section{4. タンパク食糧に関する研究（第 3 報）尿素処理法による酵母分 離タンパク質の栄養価について 満田 久輝, 中村 尚夫, 河合 文雄 (京都大・農) 鹿内 健彦（大阪成蹊女子短大）}

演者らは先にタンパク食糧資源開発を目的として, 醅 母よりタンパク質を分離抽出する方法を検討し, 高茎度 の尿素溶液による浸清抽出法が有効なことを明らかにす るとともに，この方法による分離タンパク質はカゼイン に匹敵する人工消化率を示すことを明らかにした。

今回は, 動物による消化率, 栄養価を検するととも に, 尿素処理がタンパク質の栄養価に及ほす影䇾を検す るため, 尿素処理法に上る醉母分離タンパク質, 尿素処 理したカゼイン, 原料醭母, 原料カゼインによるネズミ の飼育試験を行ない, 成長曲線を比較するとともに, 消 化率, 生物価を測定した。

酵母分離タンパク質は10M尿素溶液, 40度, 72時間浸 漬, 酸沈段法によって調製し, 尿素処理カゼインは市販 カゼインに同様の処理を行なって調轅した。

幼ネズミによる消化率は, カゼイン $96 \%$, 尿素処理カ ゼイン $93 \%$ ，酵母分離タンパク質 $96 \%$ で大差なく，きわ めて良好であるが，原料醉母は66\%で著しく劣る。生物 価は, カゼイン69, 尿素处理カゼイン67で大差はなかっ

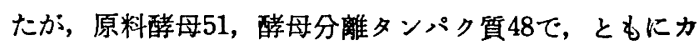
ゼインに比して著しく低い。これは本来, 酵母タンパク 質の含硫了ミノ酸含量が少ないためと考えられ，分離夕 ンパク質にメチオニンを補足すると生物価は61となり, 著しく向上した。

タンパク質 $25 \%$ 飼料による成長試験では, カゼイン, 尿素処理カゼイン, メチオニン補足醉母分離タンパク質 のタンパク効率はそれぞれ 2.4, 2.5,2.3で，とすに類 
似の成長曲線を示し，醅母分離タンパク質，原料醉母の タンパク効率はそれぞれ 1.7，1.6 で, 類似の成長曲線 を示すが，その成長はカゼインなどの場合に比してはる かに劣る。

以上，尿素処理法はタンパク質の栄养価をそこなわな い，有効な方法であると考える。

105. アミノ酸のガスクロマトグラフ ィー一生体試料分析のための 誘導体, カラムの検討

福島 秀夫, 斎藤 史郎, 中村 栄一 織田 敏次, 吉利 和

（東京大・医・吉利内科）

すでに報告したジニトロフェニルアミノ酸誘導体を用 いる方法 (DNP-フミノ酸法)では, アミノ酸の抽出法, 内部標準について検討しトリフルオロアミノ酸誘導体 を用いる方法 (TFA-アミノ酸法) では血漿遊離つミノ 酸分析への応用を試みた。

1） DNP-アミノ酸法：DNP-アミノ酸の抽出はェー テル（弱フルカリ性）洗浄, 酢酸エチル（pH 3.0 以下） の抽出では十分でなく，DNP 化の処理の前にアルニー 儿除蛋白，クロロホルム（pH 3.0 以下）洗浄を行なう ことによりほぼとの目的を達することができた。この処 理の回収率は92.5\%である。定量には内部標準に $\varepsilon->$ ミノカプロン酸を生体試料に加えて処理を行ならことに より，試料は $1 / 2$ 量ですむ。

2） TFA-アミノ酸法：前法で生体試料中で検出でき るアミノ酸は約 10 種で限られており，塩基性つミノ酸な ど分析が困難である。TFA-フミノ酸誘導体は揮発性が すぐれ，ほとんどすべてのアミノ酸が検出できるとされ るが，生体試料とくに血液への応用はされてない。へパ リン血漿よりアミノ酸の抽出は, (a) DNP-アミノ酸法 で用いた有機溶媒を用いる方法，(b) イオン交換樹脂を 用いる方法 (回収率約 $95 \%$ ) の 2 つの方法で検討し，(a) は（b）に比べ短時間で行なえ，簡単な方法であるが, （b）に比べクロマトグラムの基線がやや高い。つぎに抽 出されたアミノ酸試料を塩酸飽和メタノール中でエステ ル化し，真空乾燥させる。えられたアミノ酸メチルェス テル塩酸塩を塩化メチレンに溶かし, 無水三弗化酢酸を その約 $1 / 10$ 量加えて室温で 2 時間かくはんしてアミル化 し, 減压乾固してアセトンに溶かしてNeopentyl glycol succinate 充填カラムに注入する。その結果標準試料に ついては蛋白粠成のほとんどすべてのアミ/酸で検出可 能であり，血漿試料では10数種のアミノ酸で同定するこ とができた。
106. 有效性リジンの定量値に及ぼす 試料調製法の影響について

品川 孝雄, 垣生 俊夫（愛媛大・農）

食品蛋白質のアミノ酸組成の研究と併行して, 有効性 リジンの定量を行ならに当たり, 試料の調製方法か，有 効性リジン含量に及はす影瑤について検討した。

試料調製方法は，a）前報と同様，アセトンにて脱水 後, 自然乾燥する。b) $50^{\circ} \mathrm{C}$ の熱風乾燥器中で, 15 時 間乾燥する。C ) $95 \sim 98^{\circ} \mathrm{C}$ の乾燥器中で, 8 時間乾燥 する。以上の三方法によって調彆した数種の植物性なら びに動物性食品試料中の有効性リジン含量と, 微生物法 によるリジン含量との比較検討を行なった。なお，有効 性リジンの定量は, Carpenter の DNP-法によった。

その結果, DNP-法による有効性リジンの含量は, 動 物性試料では，ａ）法によるすのに対し， b ) 法による ものは, $5 \sim 6 \%, c$ ) 法によるものは, 10〜15\%の低 值となり，また，植物性試料では，a）法によるものに 対し, b ) 法によるものは, $5 \sim 8 \%, c)$ 法によるも のは，12〜15\%の低值となり，これによって加熱が定量 結果にかなり大きく影響するすのと思われる。

また，微生物法によるリジン定量値は，動物性試料で は，加熱により影響をほとんど受けないと思われるが， 植物性試料, 特に糖を多く含むるのでは, a) 法による すのに対し， b ) 法によるすのは, 僅かの低值があら れ，c）法によるものは，7〜10\%の低值が認められた。

これらのことから, 試料調製時における加熱処理は, リジン定量值に影響し, ことに $100^{\circ} \mathrm{C}$ の加熱では, 有効 性リジンの定量值は著しく低值となるものと思われる。

\section{7. 実験食としてのアミノ酸寒天混 合冷凍食慨}

$$
\begin{aligned}
& \text { 大野 満, 渡辺 達郎, 生形 圭 } \\
& \text { 小出来一博 (順天堂大 ·第一外科) }
\end{aligned}
$$

われわれは, 担癌動物に対し, 特定必須了ミノ酸, す なわち，Lys. 打よび Thr. の過剩負荷実験を行なって いるが，その実験食として，従来とは異なった，フミ， 酸寒天混合冷凍食餌を用い，良好な結果を得ているので 報告する。

従来使用していな実験食は， Rose の適正比率を改良 した基本つミノ酸組成に,トゥモロコシ澱粉，シュクロ 一ス, 塩混合, 大豆肝油ビタミン, お上び少量の塩化ュ リンを摄氏約 $50^{\circ} \mathrm{C}$ の等量の水で混合したものであった が，1965年，Harper らの，煮沸した寒天ゲル状液に等 量のフミノ酸混合食飰をまぜ合わせた飼料で，シロネズ 
栄養

ミの発育に良い結果を得たという報告に着目し，従来の 食慨を改良したアミノ酸寒天混合冷涷食慨を作成した。

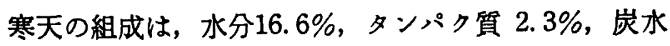
化物 $76.2 \%$ ，エーテル抽出物 $0.3 \%$, 線維 $0.8 \%$, 灰分 $3.9 \%$ であり, 炭水化物の主成分は, ガラクトースであ り, 少量の使用では蛋白質としての栄養的価値はゼ口と 考えてよいものである。この実験食の慗法は，3\%寒天 液の煮沸したゲル状液の中へ，アミノ酸混合食を等量加 え, 上く混合し, 四角形の棒状とし, これを摄氏 $0^{\circ} \mathrm{C}$ から $4^{\circ} \mathrm{C}$ の冷蔵庫に保存したものである。

この実験食の利点は, 保存の利く食䬲を一度に大量作 れ, 従って, 毎日作成するという時間的ロスが全くなく なることである。次に, 冷蔵庫に保存するためフミノ酸 臭が大分消失し，摄取状況が良いことである。さらに寒 天の性質上，食慨のまとまりが非常に良いことである。 シロネズミの成長に関しての実験では, 普通, 動物舎で 使用している飼育食としての固形食には, 体重增加の点 で, 多少劣るが, 血清蛋白像では優れており, 実験食と して十分使用できるすのである。

われわれは,この害験食を用い, 担癌動物に対する実 験を行ない, 特定アミノ酸過剩負荷による, 種々の影響 を検討したので併わせて報告する。

\section{Lactobacillus bulgaricus の胆汁 耐性菌について（第 1 報）胆汁 耐性菌の育成}

青島 郁子（日本女子大）

L. bulgaricus はいろいろな酸乳, 酸酵乳に使われて いる乳酸菌であるが, 経口提取後, 消化器系を通過する 間に，種々な作用をうけ生育を阻止されてしまう。その 阻止物質の一つといわれる胆汁に対し耐性獾得を試み,

2,3 の知見を得たので報告する。

1. L. bulgaricus は低酸型 2 菌株と高酸型 2 菌株を 使用したが，胆汁に対する生育限界濃度は，前者が $18 \%$, 後者は $1 \%$ 以下であった。また比較のために供試した L. acidophilus は24\%であった。

2. 胆汁耐性獲得は困難であったが, 胆汁接触後, 基 本培地にもどしてから, 次のより高い胆汁濃度に移すこ とをくり返して，L. acidophilus の生育限界濃度にまで 胆汁耐性を獲得させることができた。

3. 耐性菌は感性菌にくらべ, 約 $5 \sim 8$ 倍の細胞の異 常伸長が認められた。

4. 感性菌と耐性菌について乳酸醸醉力を比較したと ころ, 殆んど差が認められなかった。

5. 耐性菌を(1)基本培地で液体培養, (224\%胆汁添加
培地で夜体培養, (3)24\%胆计添加培地で穿刺培養とい5 3 条件で，それぞれ接種菌の增殖をみてから冷蔵庫中で 保存し,一定期間後, 調査したところによると, (1)(2)(3) とも，50日後でもその獲得耐性を維持していた。

\section{9. 肝酵素誘導に及ぼす食慨の影響}

$$
\begin{aligned}
& \text { 井上度三, 中野司, 和田 富雄 } \\
& \text { 島本 雅典, 青木 敏郎, 米田 照子 } \\
& \text { （奈良医大·生化） }
\end{aligned}
$$

動物の発育には三大養素を十分に投与することが必要 条件であり, 特に消耗性疾患には高蛋白, 高脂肪食を供 給すべきことが強調されている。しかしこれらの食慨を 異常に供給してもその生物体は異常な発有を遂げること はない。これにはいろいろな調節機構があって homeostatic な状態を維持しているに違いない。それをわれわ れは単に尿排泄物からその恒常性を推測しているにすぎ ない状態である。そこでわれわれは複雑な調節機桡を解 明する前に食慨により, 肝䁍酵素群に対してどのような response を示すかを数種の酵素,すなわちトリプトファ ンの代謝に扣ける T Pase, 尿索生成に重要な役割を果 す Arginase, ミトコンドリフの機能や, 各種の生合成 反応に関与する P Pase, その他了ルカリホスファター ゼ，酸性ホスファターゼなどについて興味ある知見を得 たので報告する。実験動物には雑系白ネズミ, 同腹系す を at randomに 5 匹す゚つ取り出し, Oriental 固形飼料 と水を十分に供給したすのを対称群とし，5\%Grycerol 投与群, 高脂肪食（バター塗布）群，15\%およよ゙60\%力 ゼイン強化食群に批ける体重の変動および，上記醭素群 については, その活性変動との間に興味ある関係を見出 し, その成果を発表する。

\section{0. 治療食に関する研究（II）}

（食品構成，とくに脂肪組成の 变動による代謝位相への影響)

\section{上月 钽子 (兵庫県立西宮病院)}

さきに成人病食慨療法研究の一環として, 同カロリ一 で栄養組成を一定とした上，脂肪組成を動物性と植物性 に分けた食慨モデルを作成し，代謝異常の認められない 軽症結核患者を対象に観察した結果, 栄養状態, 治療効 果には著変なく，脂肪組成の変動は体代謝位相に多大な 影響をすたらすことが考察できた。しかし，血清蛋白， 血糖値への影響など不明の点もあり, 今回, 食䬲内容の バランスあるいはカロリーなどの吟味の必要上, 条件を 変えた食慨モデルを作成し，追試を試みた。

すなわち, 対象は前回実験時と同様, 軽症結核患者と 
した。コントロール食として, 前回同カロリー $(2,700$ Cal) で, しかわ，高脂肪 $(80 \mathrm{~g})$ 高蛋白 $(100 \mathrm{~g})$ 食で あったものを, カロリーを減らし, 普通病人食投与範囲 （熱量 $2,200 \mathrm{Cal}$, 脂肪 $50 \mathrm{~g}$, 蛋白質 $80 \mathrm{~g}$ ) にとどめ, 期間す12週間を 6 週間に短縮, 身長, 体重, 血糖, 血中 蛋白, 血圧, 総コレステロール, 肝機能 (Co.R) に加元 て A/G 比, 尿中クレアチン, クレフチニン, 尿量など について観察した。

食慨組成分析に関しても，前回，1 日単位で考察を行 なったのであるが，消化吸収の機序などを考萝し，1日 単位とし，それぞれについて三大栄荃素に加えて微量成 分の検討も行なった。脂肪組成の比率は, 前回, (A)(D)食 動物性, 植物性各 $50 \%$ 平均であり, 今回もまた同様であ る。(B)食では，動物性 90\%，植物性 10\% であったもの か，今回，動物性 $75 \%$, 植物性 $25 \%$ の比率となり, 相当 の差がある。また，(c)食は動物性40\%，植物性60\%であ ったのであるが，これは(A)(D)食とす大差ない。

以上，食䬦組成の差ならびにカロリ一差による变動を 比較検討した結果, 血糖, 血清蛋白量, 今回検索した $\mathrm{A} / \mathrm{G}$ 比, 尿中クレアチン, クレアチン排泄量にみるべき所見 を得，とくに蛋白代謝上への影響が伺光，栄養素内容の 他，摄取総カロリーの影響をも十分考虑せねばならない ことが判明した。

\section{1. 妊婦の血液像と栄養との関係に} ১いて

\section{前原 大作，菊地 フク（東芝鶴見病院）}

妊娠, 分婏, 産袮期の多岐にわたる母体の代謝のため に，妊産婦に特別な栄養が必要であることは周知のこと である。

妊産婦に栄養が不足すると，流早産をおこし，胎児の 発育を阻害したり，また母体の代謝に悪影響を及はして 来るが，最近とくに注目されて来た妊婦の貧血がある。 めまい, 動悸などの自覚症状はなくても, 妊婦の血液像 をみると，相当高率に貧血が発見されている。この妊婦 の負血は鉄欠乏に由来するといわれ，栄美摂取状況と深 い関係にあると考えられる。そこで私らは当病院に通院 中の娃婦（妊娠第 5 カ月以後の者）50例に掑取食事を詳 細に 3 日間連続して記入させ, 同時に血液像 (血色素 量,へマトクリット値, 赤血球数）を測定し，掑取食品の 種類とその栄美素 (热量, 㔻白質, 脂肪, カルシウム, 鉄, V.A, V.B $B_{1}$, V. $B_{2}$, ナイフシン) を算出し, 血液所 見との関係について検討したので報告する。

\section{2. 病人食事の消化吸収試験}

\section{（第 5 報）}

$$
\begin{aligned}
& \text { 原実, 松木 光, 蔵田智恵子 } \\
& \text { （磨応大·医・食研） }
\end{aligned}
$$

当病院入院患者（胃癌ならびに食道癌）の術後の栄養 管理に際し，早期より経管食を用い，術後の回復上好成 續を認めたことはすでに発表したが，今回はこれらの患 者の術後,ならびに術後 1 力月後（退院時）における消 化吸収試験を行なった成績について報告する。

被検者は, 術後高蛋白流動食給与の者 4 名, 退院時常 食給与の者 6 名, 計10例について, 常法により 5 日乃至 1 週間, 消化吸収試験を行なった。

給与食事の栄美量は，高蛋白流動食に扎いては，熱量 $2,053 \mathrm{Cal}$, 蛋白質 $67.3 \mathrm{~g}$, 脂質 $21.4 \mathrm{~g}$, 糖質 $394.5 \mathrm{~g}$, 水 分 $1,706 \mathrm{cc}, 1$ 日給与量 $1,265 \mathrm{~g}$ であり, 退院時試験食の 食篦による栄美量は, 熱量 $2,072 \mathrm{Cal}$, 蛋白質 $81.6 \mathrm{~g}$, 脂 質 $45.3 \mathrm{~g}$ ，糖質 $331.6 \mathrm{~g}$ であった。

なお，各ヶの残量については秤量して搑取栄養量の算 出を行なった。

結果, 実験成績は次のごとく, 術後被検者平均では蛋 白質 $81.5 \%$ ，脂質 $75.8 \%$ ，糖質 $96.1 \%$ であり，退院時平 均蛋白質 $83.1 \%$, 脂質 $85.2 \%$, 糖質 $98.6 \%$ に, 糖質の 場合はいずれの場合す健康例と大差なく, 脂質の吸収が かなり劣るか，蛋白質の吸収は 1 例を除くほかは比較的 良好であった。

$\mathrm{N}$ 出納は（一）を示すもの術後 4 例中 3 例, 退院時 6 例中 3 例であった。

\section{3. 粪便の消化度よりみた経口栄養 補給についての一考察(第 1 報)}

$$
\begin{aligned}
& \text { 長田 博之, 正井 英一, 神木 照雄 } \\
& \text { 金光 綏子（国立大阪病院） }
\end{aligned}
$$

胃切除術後の患者の経口的栄養補給についてはすでに 多くの研究がなされたり, 現在では高蛋白, 高カロり 一食が推奖されている。しかし胃切除術後食は患者の精 神的, 生理的な食欲不振があって，あまり多くの栄盖量 とはなっていない現状である。実際に胃切除術後食を摂 取している患者から得た整便を顕徽鏡学的に観察したが その堡便には不消化な食物残渣が案外少なく，殆んど認 められない事実が判明した。この事実は現在実施してい る術後食を患者が量的に多くを摄取していないのか，ま たは実際に摂取していても，十分なる消化が行なわれて いて不消化食物残渣が認められないとい5，2つの場合 をさしているのではないかと考えられる。るし第 2 の場 
合のように患者が所定量の食事を全量摂食していて,な おその翼便中に不消化性食物残渣が認められないとすれ ば,さらに多くの蛋白質と脂肪，糖質を与えることが可能 となる。そこでわれわれは健康人に高カロリー, 高蛋白食 を与え, 飽食的不消化の状態を䔬便の顕微鏡的検査によ り確認した後, 配合消化䤃素㓣を与えて不消化性食物残 查の消失を認めた。健康人と術後患者とでは全くその消 化機能に共通の状態があるとは思えないか，先述の術後
患者蕒便に殆んど不消化性食物残渣の認められない事実 を考虑すると，術後患者にす消化䤃素と共にさらに高蛋 白, 高カロリー食を与えることにより街後の回復を良好 ならしめるのではないかと考察する。今回は健康人の飽 食および胃潰痬術後と術後食摄取患者の偵便の消化度に ついて行なった観察の結果を報告し, 術後患者にさらに 多量の栄養を与える際の一つの慗付けとしたい。

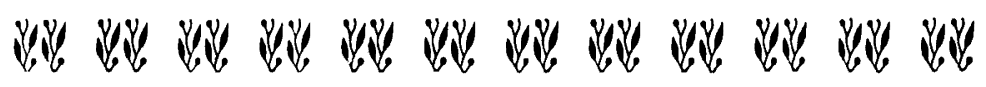

後記

去年までは第 1 号を総会号ということにして，これに 一般講演の抄録を出していたが，いろいろの都合によっ て本年からは大会々場では別につくった要旨を配りこ れをさらに訂正したものを第 2 号に載せることになっ た。つまり、ここに載せた抄録は決定版ということにな る。るっとも本年は未だこの趣旨が徹底しなかったせい か, 大会に配ったものと同じもの，例えば『何々につい て述べたいと思5』式のすのが，演者からの訂正がない ままにそのまま載っているすのもいくらかあるが，大会 で配ったものを書き改められたもの，あるいはさらに内 容を追加されたものるかなりある。今後は以上の趣旨を もっと徹底させてゆきたいと思う。

な拈，以上のことと関連して，あるいはそ5いう要望
が強くあったので上記のようになったといった方が経過 的には正しいが, 大会以外の例会, 支部講演会などにつ いても, 爾後において講演の抄録を本誌に載せてゆくこ とになっている。これる当然, 講演会当日に配布の要旨 と同じすのでなく，決定版という建前においてである。

（以上のような建前になったために馝案になっていた 一昨年の近畿支部大会の抄録を甚だおそくなったが本誌 に載せる。)

なお，本誌に『必須つミノ酸研究委員会』(委員長 島 薗順雄氏）の抄録を記事として載せているが，これは前 記のこととは関係なく, 会員並びに委員会の便宜をはか ってのことであるので，るし載せなくてよいという声か 大きければ省いてるよいわけである。

(以上) 